\title{
Prevalence of Toxigenic Fungi in Egyptian Smoke-Dried Herring Fish: I- Antifungal Activity of Basil (Ocimum basilicum L.) Essential oil
}

\author{
Ahmed A. Ismaiel \\ Department of Botany, Faculty of Science, Zagazig University, \\ Zagazig, Egypt.
}

\begin{abstract}
SURVEY was carried out on malt salt agar media to isolate and A evaluate mycoflora occurring in samples of smoke-dried herring fish (Clupea harengus L.) that are ready for human consumption in Egypt. Aspergillus species were the most abundant fungi followed by Penicillium species then Fusarium species. Fungal genera of Cladosporium, Epicoccum, Mucor, and Rhizopus species were also isolated. A. flavus and A. fumigatus were the most frequently isolated aspergilli. $P$. griseofulvum was the most species common among penicillia, and $F$. solani was the predominant Fusarium species. $C$. cladosporioides was recovered in a high incidence. Findings of mycotoxins formation by the isolated mycoflora showed that some mycotoxins (aflatoxins, cyclopiazonic acid and kojic acid) were produced by some isolates of A. flavus. Some isolates of A. niger and A. fumigatus were able to produce kojic acid. A. ochraceus isolates produced penicillic acid but were not able to produce ochratoxin A. Two isolates of $A$. parasiticus were aflatoxin $\mathrm{B}_{1}$-producing and one isolate of $A$. versicolor produced sterigmatocystin. Concerning Fusarium species, some isolates of $F$. oxysporum and $F$. solani had the ability to produce cyclosporin A and zearalenone. The antibiotic, griseofulvin, citrinin and patulin were the characteristics metabolites produced by the toxigenic isolates of Penicillium species. This study was also extended to evaluate the efficacy of different concentrations of Ocimum basilicum L. essential oil on in vitro activity against the toxigenic isolated moulds. The recorded minimum inhibitory concentration (MIC) of the essential oil was $15 \%(\mathrm{v} / \mathrm{v})$ with all the tested mould strains except $A$. niger, A. ochraceus (the MIC value was $10 \%, \mathrm{v} / \mathrm{v}$ ) and Penicillium species (the MIC value was $20 \%, \mathrm{v} / \mathrm{v}$ ). This oil was found to be fungicidal at all the tested concentrations. These findings indicate the possibility to use $O$. basilicum essential oil as a substitute for chemical additives to control fungal growth and toxins production
\end{abstract}

Keywords: Mycoflora, Mycotoxins, Smoke-dried herrings, Ocimum basilicum L., Essential oil, Antifungal.

Microscopic filamentous fungi are ubiquitous microorganisms with a great capacity to colonize many kinds of substrates and to proliferate under extreme environmental conditions (Nguefack et al., 2009). Aspergillus, Penicillium and Fusarium are the most important causing spoilage of food stuffs (Singh et al., 1991). Mould contamination is often associated with unpleasant appearance, odor 
and changes in taste and nutritional value of foods (Filtenborg et al., 1996). Moulds produce mycotoxins that can be teratogenic, carcinogenic or cause feed refusal and emesis (Yu et al., 2003 and Magan et al., 2004). Toxic syndromes caused by mycotoxin ingestion by humans and animals are indicated as mycotoxicosis (Galvano et al., 2001).

Fish is an important commodity in the diet of most people in Egypt. Nutritionally, fish proteins are highly digestible and at least as good as red meat with respect to content of essential amino acids (Norman \& Joseph, 1996). Because of the great tendency of fish to spoil, a number of methods of preservation have been developed over the years. The most basic methods are smoking and salting with subsequent drying. This is effective but such preserved fish are not accepted in all cultures. Other societies have found that such preserved fish is highly desirable (Oyewole et al., 2006).

Little information has been published on toxigenic mycoflora of smoke-dried fish. The most important studies to date are those of Jonsyn \& Lahai (1992) which demonstrated the presence of A. flavus and A. ochraceus in smoke-dried fish of Ethmolosa sp. that are potential for production of aflatoxins and ochratoxin A, respectively. A related study on smoked shark fish (Essien et al., 2005) revealed the predominance of Aspergillus, Penicillium, Eurotium, Fusarium and Cladosporium species in this product, although the potential production of mycotoxins types by these mycoflora, were not detected in their study.

Plant extracts, especially volatile essential oils from medicinal plants, have been reported to possess antimicrobial activity against a variety of food-borne, human and plant pathogens and pests (Burt, 2004 and Soylu et al., 2007). The antimicrobial properties of basil essential oils have also draw a great attention from many researchers (Suppakul et al., 2003; Piyo et al., 2009 and Saggiorato et al., 2009). The major components of basil (Ocimum basilicum L.) responsible for its antimicrobial properties had been analyzed previously (Oplachenova \& Obreshkova, 2003; Suppakul et al., 2003 and Viyoch et al., 2006).

The objective of this study was to identify and evaluate the mycoflora occurring in different samples of smoke-dried herring fish that are ready for human consumption in Egypt. In addition, the potential mycotoxins production of isolated mould strains and the in vitro evaluation of $O$. basilicum L. essential oil along with its fungicidal activities against the isolated mould strains were investigated.

\section{Samples collection}

\section{Material and Methods}

Twenty-eight samples of herring fish (Clupea harengus L.) were randomly purchased from seven Egyptian fish processing centers namely; Abou El-Dahab, El-Bahreen, El-Gamal, El-Malekha, El-Mohamadia, El-Warda El-Baieda and Egypt (four samples each) at Sharkia Governorate. The salt concentration in the samples was in the range of 3.5 to $15 \%$. The samples were handpicked with

Egypt. J. Microbiol. 45 (2010) 
sterilized glove hands and taken to the laboratory in a separate sterilized polyethylene bags to avoid contamination from handling.

\section{Isolation and identification of fungi}

Serial dilution technique was adopted for isolation of fungi according to Fafioye et al. (2008). Ten grams of tissue portion of each fish sample was cut from the abdominal region with a sterile forceps, grinded aseptically in porcelain mortar and blended for $10 \mathrm{~min}$ in a high-speed blender with $90 \mathrm{ml}$ of sterile $0.1 \%$ peptone-water. Serial dilutions were carried out in the same diluent and $1 \mathrm{ml}$ of each dilution was spread on malt-salt agar plate containing $20 \mathrm{~g}$ of malt extract (Difco), $50 \mathrm{~g}$ of $\mathrm{NaCl}, 400 \mu \mathrm{g}$ chlorotetracycline and $13 \mathrm{~g}$ of agar (Difco) per liter. The chlorotetracycline was added just prior to pouring the plates. An additional portion of $10 \mathrm{~g}$ tissue portion from each sample were surface disinfected for $1 \mathrm{~min}$ in $5 \% \mathrm{NaOCl}$, rinsed three times with sterile distilled water and dried aseptically in a laminar flow cabinet for $2 \mathrm{hr}$ before blending and plating as described above. All plates (triplicate for each sample) were incubated at $28 \pm 2^{\circ} \mathrm{C}$ for 7 days. The results were expressed as CFU per gram of fish sample. Colonies representative for each type were transferred for sub-culturing on to plates with malt extract autolysate (MEA) agar.

Taxonomic identification of the different genera and species was made according macroscopic and microscopic morphological criteria in accordance with appropriate keys. Aspergillus species were identified according to Raper \& Fennel (1965) and Samson et al. (2007 a, b). For the species belonging to the Penicillium genus, growth was also observed on three selective media; Czapek yeast autolysate (CYA) agar, malt extract autolysate (MEA) agar and yeast extract sucrose (YES) agar (Frisvad \& Samson, 2004). Fusarium species were cultured on potato dextrose agar and identified with other fungal species according to Domsch et al. (1980) and Gilman (1957).

\section{In vitro production of mycotoxins by fungal isolates}

An agar disc (6 mm, diameter) of each pure fungal isolate growing on to MEA agar plate for 7 days, was transferred aseptically to $250 \mathrm{ml}$ Erlenmeyer flasks (triplicate for each fungal isolate), each containing $50 \mathrm{ml}$ of freshly prepared, sterilized broth medium (Aziz \& Moussa, 2002). The medium contained $5 \mathrm{~g}$ of Difco mycological peptone, $20 \mathrm{~g}$ of yeast extract, $40 \mathrm{~g}$ of sucrose and $1 \mathrm{~L}$ of distilled water ( $\mathrm{pH} 5.5)$. Flasks were stationary incubated in the dark for 14 days at $28^{\circ} \mathrm{C}$.

\section{Mycotoxins analysis}

Extraction of mycotoxins from fungal cultures

At the end of the incubation period, the contents of each flask (medium + mycelium) were homogenized with either chloroform (for extraction of aflatoxins, citrinin, cyclopiazonic acid, griseofulvin, ochratoxin A and sterigmatocystin) or ethyl acetate (for extraction of cyclosporin A, patulin, penicillic acid and zearalenone) by a rotary shaker $(200 \mathrm{rpm})$ overnight. The 
extraction procedure was repeated three times. The extracts were sequentially filtered through anhydrous sodium sulfate then concentrated to near dryness.

Simple screening methods were used to detect the formation of some mycotoxins by the isolated fungal species. For aflatoxin-producing isolates, the presence of aflatoxins was determined by examining the reverse side of Petridishes cultivated with the tested isolate on coconut agar medium under UV-light (366 nm) (Lin \& Dianese, 1976). For screening of kojic acidproducing isolates, the presence of kojic acid in their water dissolved extract was determined by the color test of Bentley (1957) using $\mathrm{FeCl}_{3}$ as a reagent. Detection of penicillic acid in water dissolved extract of the screened fungal isolates was done by adding excess of concentrated ammonia as described in the color test of Bentley \& Keil (1962). These tests were used as rapid screening methods to detect aflatoxins, kojic acid and penicillic acid produced by the tested fungal isolates. However when positive, the confirmation of their formation was achieved by thin-layer chromatographic technique as shown, as follows.

Thin-layer chromatography (TLC) of mycotoxins

Mycotoxin detection was performed using TLC on silica gel plates (20x $20 \mathrm{~cm}, 0.25 \mathrm{~mm}$ thick, GF-254), at room temperature in a non-saturated chamber. The concentrated extracts were examined on the TLC plates together with the following standards: Aflatoxins $\left(B_{1}, B_{2}, G_{1}\right.$ and $\left.G_{2}\right)$, citrinin, kojic acid, ochratoxin $\mathrm{A}$, patulin, penicillic acid, sterigmatocystin, zearalenone (Sigma Co., Louis St., USA), cyclopiazonic acid (Wako, Pure Chemical Industries, Ltd., Japan), cyclosporin A (Sandimmun, Novartis Pharma AG, Basle, Switzerland), griseofulvin (Kahira Pharm.\& Chem. Ind. Co., Cairo, Egypt). For some acidic metabolites like cyclopiazonic acid, citrinin, penicillic acid, the plate was impregnated in an $8 \%$ solution of oxalic acid in methanol (El-Shanawany et al., 2005). Toluene-ethyl acetate-90\% formic acid (6:3:1; $\mathrm{v} / \mathrm{v} / \mathrm{v})$ eluting mixture was used to develop the TLC plates. The mycotoxins were visualized in UV light at 254 and $366 \mathrm{~nm}$ (UV-254 and UV-366) before and after treatment as listed in Table 1.

\section{In vitro antifungal testing}

Essential oil

Ocimum basilicum L., commonly named basil, was kindly obtained from Sekem Company, Hikstep region, Cairo, Egypt. This essential oil was selected on the basis of its highest broad spectrum and activity against the tested fungi during a screening test was done on a total of 9 types of essential oils.

Preparation of different concentrations of essential oil

Different volumes of the basil essential oil were diluted in different volumes of an aqueous solution of tween-80 to give the following concentrations: $5,10,15,20,25$ and $30 \%$.

Egypt. J. Microbiol. 45 (2010) 
TABLE 1. Visualization techniques used for detection of mycotoxins on TLC plates .

\begin{tabular}{|c|c|c|c|c|}
\hline \multirow{2}{*}{ Mycotoxin } & \multicolumn{2}{|c|}{ Fluorescence colour } & \multirow{2}{*}{ Visualization } & \multirow{2}{*}{ Ref. } \\
\hline & UV-254 & UV-366 & & \\
\hline Aflatoxins & & & & Scott et al. (1970) \\
\hline Aflatoxin $\mathrm{B}_{1}$ & Faint blue & Blue & & \\
\hline Aflatoxin $\mathrm{B}_{2}$ & Faint blue & Blue & & \\
\hline Aflatoxin $\mathrm{G}_{1}$ & Faint green & Green & & \\
\hline Aflatoxin $\mathrm{G}_{2}$ & Faint green & Green & & \\
\hline Citrinin & Yellow & Yellow & $\mathrm{I}_{2}{ }^{\mathrm{a}}$, orange & $\begin{array}{l}\text { (Scott } \text { et al. } 1970 ; \\
\text { Grost-Allman \& } \\
\text { Steyn, 1979) }\end{array}$ \\
\hline Cyclopiazonic acid & Purple & & $\begin{array}{l}\text { EH reagent, bluish- } \\
\text { purple }\end{array}$ & $\begin{array}{l}\text { Mphande } \text { et al. } \\
\text { (2004) }\end{array}$ \\
\hline Cyclosporin A & Violet & & $\mathrm{I}_{2}{ }^{\mathrm{a}}$, brown & $\begin{array}{l}\text { Dreyfuss } \\
\text { et al.(1976) }\end{array}$ \\
\hline Griseofulvin & Blue & $\begin{array}{l}\text { Bright } \\
\text { blue }\end{array}$ & & Cole et al. (1970) \\
\hline Kojic acid & & Pale green & $\begin{array}{l}\mathrm{FeCl}_{3}+\mathrm{UV}(366), \text { dark } \\
\text { (F) }\end{array}$ & $\begin{array}{l}\text { Duračková et al. } \\
\text { (1976) }\end{array}$ \\
\hline Ochratoxin A & Blue & Blue-green & $\mathrm{FeCl}_{3}$, purple brown & $\begin{array}{l}\text { Grost-Allman \& } \\
\text { Steyn (1979) }\end{array}$ \\
\hline Patulin & & Yellow & PH+heating, yellow & $\begin{array}{l}\text { López-Diáz et al. } \\
\text { (1996) }\end{array}$ \\
\hline Penicillic acid & & Dark blue & $\begin{array}{l}\text { Amm.theating+UV } \\
(366) \text {, blue }(F)\end{array}$ & $\begin{array}{l}\text { Ciegler \& } \\
\text { Kurtzman (1970) }\end{array}$ \\
\hline Sterigmatocystin & & Red brown & $\begin{array}{l}\mathrm{AlCl}_{3} \text { +heating+ } \\
\mathrm{UV}(366), \text { yellow (F) }\end{array}$ & $\begin{array}{l}\text { López-Diáz et al. } \\
\text { (1996) }\end{array}$ \\
\hline Zearalenone & Blue-green & Faint blue & $\begin{array}{l}\mathrm{AlCl}_{3} \text { +heating+ } \\
\mathrm{UV}(366) \text {, dark blue }(\mathrm{F})\end{array}$ & Aziz et al. (1998) \\
\hline
\end{tabular}

${ }^{a}$ Plate kept in iodine vapor for $15 \mathrm{~min}$; $\mathrm{EH}$, Ehrlich's reagent (1g of dimethylaminobenzaldehyde dissolved in a mixture of $75 \mathrm{ml}$ of ethanol and $25 \mathrm{ml}$ of concentrated $\mathrm{HCl}$ ); $\mathrm{FeCl}_{3}, 1 \%$ solution of Iron (III) chloride in ethanol; $\mathrm{PH}$, phenylhydrazine $4 \%$ in water; Amm., ammonia vapour treatment for $10 \mathrm{~min}$; $\mathrm{AlCl}_{3}, 20 \%$ solution (w/v) in ethanol; heating, $105-110^{\circ} \mathrm{C} / 5-10 \mathrm{~min}$; (F), Fluorescence.

\section{Antifungal assay of $O$. basilicum essential oil}

The effectiveness of each concentration was evaluated using cut plate diffusion method in which, a hole of $1 \mathrm{~cm}$ diameter was cut in each plate using a sterilized cork borer. The plates containing $25 \mathrm{ml}$ Czapek-Dox's agar was seeded with $0.1 \mathrm{ml}$ fungal spore suspension $\left(10^{5}\right.$ spores $\left./ \mathrm{ml}\right)$ from 7 days-old culture. Drops of water dissolved agar $(2 \%$, w/v) were put in holes and $70 \mu \mathrm{l}$ of the tested essential oil was pipetted into each hole. The plates were refrigerated for $2 \mathrm{hr}$ and incubated at $28 \pm 2^{\circ} \mathrm{C}$ for 5 days. Control plates without oil (with aqueous solution of tween-80 only) were also prepared in the same way. Diameter of inhibition zones was measured and the minimum inhibitory concentration (MIC) for each fungal strain was determined as lowest concentration of the essential oil that resulted in a complete inhibition of visible growth. Meanwhile, the fungicidal/fungistatic nature of $O$. basilicum essential oil was detected by cutting discs from the inhibition zones with sterilized cork borer and reinoculating on to fresh Czapek-Dox's agar and the revival of each fungal growth is being recorded (Thompson, 1989).

All tests were carried out in triplicate. The results of antifungal activity tests of basil essential oil were analyzed by ANOVA test for equality of means.

Egypt. J. Microbiol. 45 (2010) 


\section{Results and Discussion}

Smoke-dried herring fish (Clupea harengus L.) is a popular food product in Egypt due to its taste with both rich and poor, relatively cheap and is available all year-round. As might be expected, the surface disinfected herring samples showed a lower fungal contamination than that recorded in non-surface disinfected samples (Table 2). The highest total fungal count either in surface disinfected or non-surface disinfected herring samples was detected in the samples of El-Gamal, El-Malekha, El-Warda El-Baieda and El-Mohamadia, where as Abou El-Dahab, El-Bahreen and Egypt herrings had the lowest fungal counts. Fafioye et al. (2008) reported that the contamination of smoke-dried and stored fish with fungal species was as a result of hot climate that provide favorable condition for mould spores to germinate and grow on dried fish.

TABLE 2. Fungal propagules counts in colony forming units (CFU/g) for different samples of smoke-dried herring fish (Clupea harengus L.) on malt-salt agar.

\begin{tabular}{|l|c|c|}
\hline \multirow{2}{*}{ Smoked herring fish samples } & \multicolumn{2}{|c|}{ Total count per gram } \\
\cline { 2 - 3 } & NSD & SD \\
\hline Abou El-Dahab & $3.00 \times 10^{2}$ & $1.66 \times 10^{2}$ \\
\hline El-Bahreen & $4.66 \times 10^{2}$ & $3.00 \times 10^{2}$ \\
\hline El-Gamal & $6.66 \times 10^{4}$ & $6.00 \times 10^{4}$ \\
\hline El-Malekha & $4.70 \times 10^{4}$ & $4.30 \times 10^{4}$ \\
\hline El-Mohamadia & $1.10 \times 10^{3}$ & $1.03 \times 10^{3}$ \\
\hline El-Warda El-Baieda & $7.00 \times 10^{3}$ & $4.30 \times 10^{3}$ \\
\hline Egypt & $8.33 \times 10^{2}$ & $5.66 \times 10^{2}$ \\
\hline
\end{tabular}

NSD, non surface disinfected.

SD, surface disinfected.

Results presented in Table 3 indicate that almost all smoked herring fish samples examined in this study were contaminated with moulds. Aspergillus species $(20-57.5 \%)$ were the most abundant fungi. Penicillium species (7.1$36.4 \%$ ) were found in most examined samples except Egypt herrings. Fusarium species were also detected in most samples (3.90- 44.4 \%) except El-Mohamadia and El-Warda El-Baieda herrings. The mycological analysis of the smoked herring samples showed that the isolated fungal genera other than Aspergillus, Penicillium and Fusarium species, were Cladosporium, Epicoccum, Mucor and Rhizopus species. Similarly, Essien et al. (2005) found that Aspergillus and Penicillium species were the predominant moulds among Eurotium, Fusarium and Cladosporium species in smoked shark fish (Chlamydoselachus angunicus). Also, Fafioye et al. (2008) showed that the isolated fungi from various types of smoke-dried fish were Aspergillus, Penicillium, Fusarium, Mucor and Rhizopus species.

Egypt. J. Microbiol. 45 (2010) 
PREVALENCE OF TOXIGENIC FUNGI IN EGYPTIAN ...

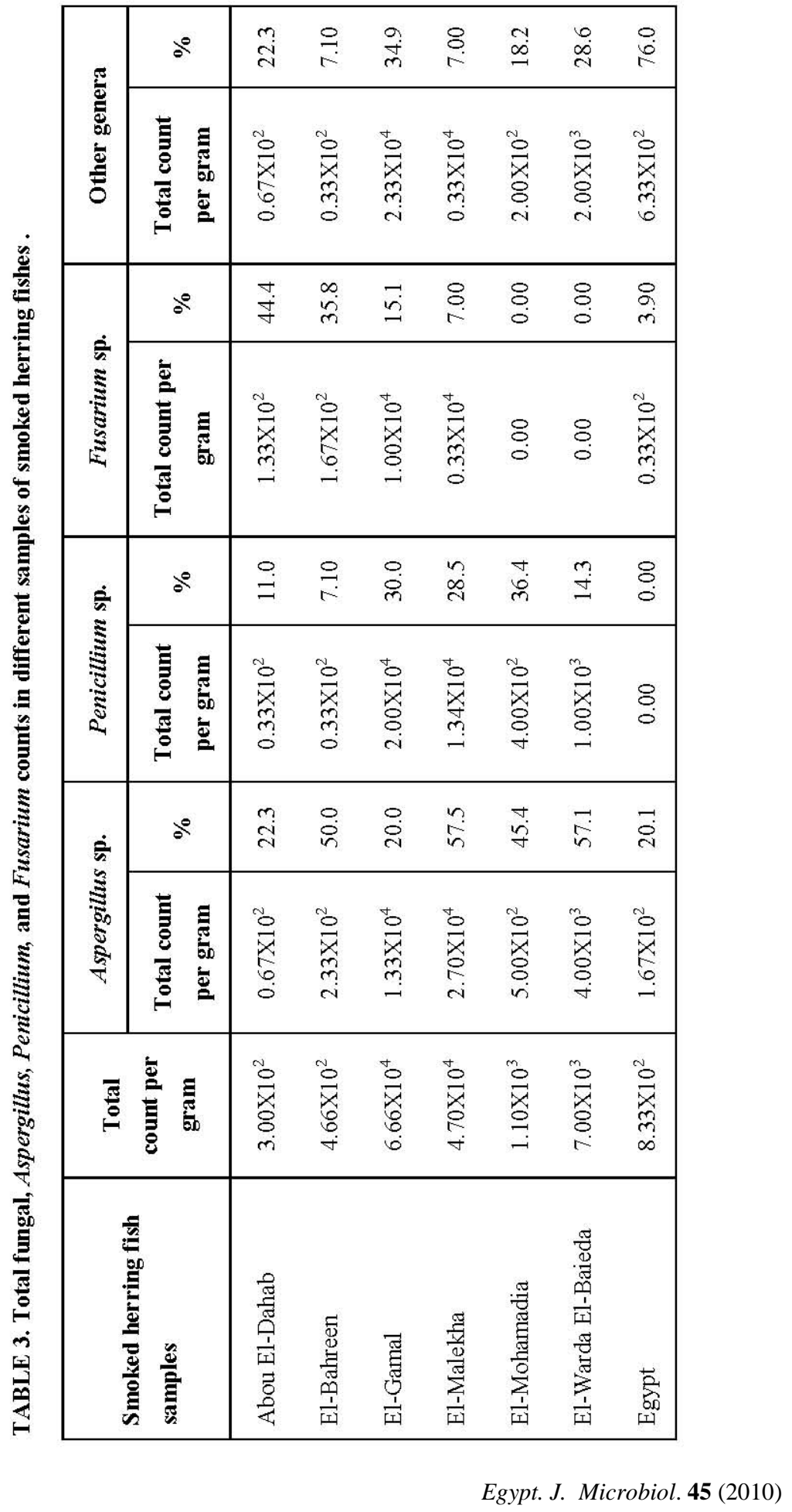


The incidence of fungal flora isolated from smoke-dried herring fish samples is presented in Table 4. A total of 16 species of fungi belonging to 7 genera were isolated and identified. Six species of Aspergillus were isolated; the most prevalent were A. flavus (100\%), A. fumigatus $(92.9 \%)$ and A. niger $(78.6 \%)$. Cladosporium cladosporioides was isolated from $92.9 \%$ of samples. Three species of Penicillium were isolated. The samples contained high levels of $P$. griseofulvum $(78.6 \%)$. By contrast, $P$. dipodomyicola and $P$. expansum were isolated at low frequency as well as that of Epicoccum sp. (14.3\%). With respect to Fusarium species, F. solani (42.9\%) was isolated in a higher contamination frequency than that of $F$. oxysporum ( $28.6 \%)$. The data also showed that the most prevalent mucorales was Mucor lamprosporus which detected in $64.3 \%$ of samples. The degree of analysis on the most frequently encountered fungi on all the smoke-dried herring samples can be arranged, as follows: A. flavus $>A$. fumigatus $=C$. cladosporioides $>$ A. niger $=P$. griseofulvum $>$ M. lamprosporus . These results were in accordance with those reported for smoke-dried fish (Fafioye et al., 2002; 2008). Domsch et al. (1981) postulated that the contamination of feed stuffs with fungal species was as a result of natural extraneous contamination by dust following storage in humid conditions.

The number of toxigenic isolates and the mycotoxins produced are shown in Table 4. In this study, all A. flavus isolates were found to be aflatoxin-producing ( 6 of them produced aflatoxins $B_{1}$ and $G_{1} ; 4$ isolates produced aflatoxins $B_{1}$ and $B_{2}$, while only 2 isolates produced aflatoxins $B_{1}, B_{2}, G_{1}$ and $G_{2}$ ). These results were in agreement with the finding observed by several authors (Jiménez et al., 1991; El-Shanawany et al., 2005 and Cary \& Ehrlich, 2006). Jiménez et al. (1991) found that 29 isolates of A. flavus were aflatoxin-producing (6 isolates produced aflatoxins $B_{1}, B_{2}, G_{1}$ and $G_{2} ; 8$ isolates produced aflatoxin $B_{1} ; 9$ isolates yielded aflatoxins $B_{1}$ and $B_{2}$ and the remaining produced aflatoxins $B_{1}$ and $G_{1}$ ). Eleven of the twelve A. flavus isolates produced cyclopiazonic acid, while kojic acid was produced by eight isolates. A. flavus was reported to produce cyclopiazonic acid (Bamba \& Sumbali, 2005) and kojic acid (Doster et al., 1996).

Eleven isolates of A. fumigatus were examined for kojic acid production. The results revealed that 2 isolates were kojic acid-producing. It is also clear that 7 of 10 isolates of $A$. niger, had the ability to produce kojic acid (Table 4). In a previous study, El-Shanawany et al. (2005) found that 4 of 12 isolates of $A$. fumigatus and all tested isolates (four) of A. niger had the ability to produce kojic acid. Kojic acid was previously recorded as a neurotoxin for human but also has antimicrobial properties (Wyllie \& Morehouse, 1977).

Aspergillus ochraceus was represented by 2 isolates and their extracts proved that the two isolates had the ability to produce penicillic acid but could not able to produce ochratoxin A. Penicillic acid had been produced by A. ochraceus isolated from red kidney beans (Sanchis et al., 1988) and has been proven to have carcinogenic nature, hazardous effects and antimicrobial properties (Macri et al., 2002 and Ezzat et al., 2007).

Egypt. J. Microbiol. 45 (2010) 
TABLE 4. Incidence of fungal species on smoke-dried Clupea harengus L. and mycotoxins production by toxigenic isolates.

\begin{tabular}{|c|c|c|c|c|}
\hline \multirow{2}{*}{ Fungal sp. } & \multirow{2}{*}{$\begin{array}{c}\begin{array}{c}\text { Frequency of } \\
\text { occurrence }^{\mathbf{a}} \\
(\%)\end{array} \\
\end{array}$} & \multicolumn{2}{|c|}{ Number of isolates } & \multirow{2}{*}{$\begin{array}{c}\text { Mycotoxin } \\
\text { detected }\end{array}$} \\
\hline & & Examined & Positives & \\
\hline \multirow{3}{*}{ Aspergillus flavus } & \multirow{3}{*}{100} & 12 & 12 & Aflatoxins $^{0}$ \\
\hline & & 12 & 11 & $\begin{array}{l}\text { Cyclopiazonic } \\
\text { acid }\end{array}$ \\
\hline & & 12 & 8 & Kojic acid \\
\hline A. fumigatus & 92.9 & 11 & 2 & Kojic acid \\
\hline A. niger & 78.6 & 10 & 7 & Kojic acid \\
\hline A. ochraceus & 14.3 & 2 & 2 & Penicillic acid \\
\hline A. parasiticus & 21.4 & 3 & 2 & Aflatoxin $\mathrm{B}_{1}$ \\
\hline A. versicolor & 28.6 & 4 & 1 & Sterigmatocystin \\
\hline $\begin{array}{l}\text { Cladosporium } \\
\text { cladosporioides }\end{array}$ & 92.9 & - & - & N.D. \\
\hline Epicoccum sp. & 14.3 & - & - & N.D. \\
\hline \multirow{2}{*}{ Fusarium oxysporum } & \multirow{2}{*}{28.6} & 4 & 1 & Cyclosporin A \\
\hline & & 4 & 2 & Zearalenone \\
\hline \multirow{2}{*}{ F. solani } & \multirow{2}{*}{42.9} & 6 & 1 & Cyclosporin A \\
\hline & & 6 & 4 & Zearalenone \\
\hline Mucor lamprosporus & 64.3 & - & - & N.D. \\
\hline M. petrinsularis & 28.6 & - & - & N.D. \\
\hline $\begin{array}{l}\text { Penicillium } \\
\text { dipodomyicola }\end{array}$ & 14.3 & 2 & 2 & Griseofulvin \\
\hline \multirow{2}{*}{ P. expansum } & \multirow{2}{*}{14.3} & 2 & 2 & Citrinin \\
\hline & & 2 & 2 & Patulin \\
\hline \multirow{2}{*}{ P. griseofulvum } & \multirow{2}{*}{78.6} & 8 & 8 & Griseofulvin \\
\hline & & 8 & 8 & Patulin \\
\hline Rhizopus stolonifer & 21.4 & - & - & N.D. \\
\hline
\end{tabular}

${ }^{\mathrm{a}}$ Number of samples from which mould were isolated / Total number of samples (\%).

${ }^{\mathrm{b}}$ two isolates yielded aflatoxins $\mathrm{B}_{1}, \mathrm{~B}_{2}, \mathrm{G}_{1} \& \mathrm{G}_{2} ; 4$ isolates yielded aflatoxins $\mathrm{B}_{1} \& \mathrm{~B}_{2}$ and 6 isolates yielded aflatoxins $\mathrm{B}_{1} \& \mathrm{G}_{1}$

N.D., not detected

Three isolates of A. parasiticus were screened in this study for aflatoxinproduction; the extracts showed that two isolates were aflatoxin $\mathrm{B}_{1}$-producing. Aziz et al. (1998) isolated A. parasiticus with a high tendency for aflatoxinproduction from some medicinal plant samples and spices.

The extracts of 4 isolates of $A$. versicolor were screened for sterigmatocystin production. Only one isolate produced sterigmatocystin (Table 4). This finding is consistent with results of others. Jiménez et al. (1991) found 2 of 6 A. versicolor isolated from sunflower seeds produced sterigmatocystin. Sterigmatocystin is a carcinogenic compound that had been shown to affect various species of experimental animals (Van der Watt, 1974).

A total of 10 Fusarium isolates (represented by 4 isolates of $F$. oxysporum and 6 isolates of $F$. solani) were examined for production of their respective toxins. Only one isolate among the tested isolates of both species had the ability to produce cyclosporin A. Production of cyclosporin A by $F$. oxysporum and $F$. solani have been reported (Sawai et al., 1981 and Sallam et al., 2003). Cyclosporin A improved the 
diminish of transplant rejection as immunosuppressive compound (Borel, 1986), however it was found to be nephrotoxic (Mihatsch et al., 1995). With regard to the screening of zearalenone production, 2 isolates of $F$. oxysporum and 4 isolates of $F$. solani were positive. Zearalenone was reported to be produced by $F$. oxysporum isolated from red kidney beans and nuts and sunflower seeds (Sanchis et al., 1988 and Jiménez et al., 1991) and F. solani (Richardson et al., 1985). It was demonstrated to have estrogenic properties (Meronuck et al., 1970).

Two isolates of Penicillium dipodomyicola were examined for production of the antibiotic, griseofulvin and patulin and the results showed that griseofulvin was detected in the extract of the two isolates but patulin was not detected. The mycotoxicosis of $P$. dipodomyicola and its ability to produce griseofulvin was reported (Frisvad \& Samson, 2004). All the tested isolates (eight) of P. griseofulvum were found to have the ability to produce griseofulvin and patulin. Also, Jiménez et al. (1991) found that 6 of 11 isolates of $P$. griseofulvum yielded griseofulvin and patulin. The data (Table 4) revealed that citrinin and patulin were detected in the extracts of 2 tested isolates of $P$. expansum. Production, teratogenicity and toxicity of patulin and citrinin from $P$. expansum were previously recorded (Ciegler et al., 1977).

A well cut diffusion method was employed for screening the antifungal activity of different concentrations of basil (Ocimum basilicum L.) essential oil $(5 \%-30 \%, \mathrm{v} / \mathrm{v})$ against the isolated toxigenic fungi. Basil essential oil revealed the highest antifungal activity against the isolated fungi among nine essential oils tested (data not shown). The obtained results (Fig. 1) indicated that the recorded MIC value of basil essential oil was $15 \%$ with all tested fungal strains except with A. niger, A. ochraceus (the recorded MIC value was 10\%) and Penicillium species (the recorded MIC value was $20 \%$ ) but the concentration of the oil at $5 \%$ showed no any inhibitory effect on the growth of the tested fungi. Piyo et al. (2009) found that basil essential oil at a concentration of $0.6 \% \mathrm{v} / \mathrm{v}$ showed mycelium growth inhibition of Fusarium moniliforme (100\%), F. proliferatum $(49.6 \%)$, Pyricularia grisea (100\%). Furthermore, they showed that at $2.0 \% \mathrm{v} / \mathrm{v}$, Bipolaris oryzae, Alternaria brassicicola and Aspergillus flavus were inhibited by 97.4, 94.6 and 59.2\%, respectively. With all tested fungal strains, the diameter of inhibition zone was clearly proportional to the concentration of basil essential oil applied to each well. Among the tested aspergilli, A. fumigatus and A. niger showed their highest sensitivity to the inhibitory effect of the essential oil at $30 \%$ (v/v) and gave rise to inhibition zone of 42 and $40 \mathrm{~mm}$ diameter, respectively; however A. versicolor and A. parasiticus showed the lowest sensitivity to the antifungal activity at the same concentration of the essential oil and gave rise to an inhibition zone of 26 and $29 \mathrm{~mm}$ diameter, respectively. The fungicidal activity of basil essential oil against wide range of fungi was reported previously (Suppakul et al., 2003 and Saggiorato et al., 2009). Resubculturing from the inhibition zone of the tested fungi on Czapek-Dox's agar plates emphasized that this essential oil has a fungicidal activity. The antifungal activity of basil (Ocimum gratissimum L.) was attributed to presence of thymol and other phenol derivatives in its composition (Koba et al., 2009).

Egypt. J. Microbiol. 45 (2010) 


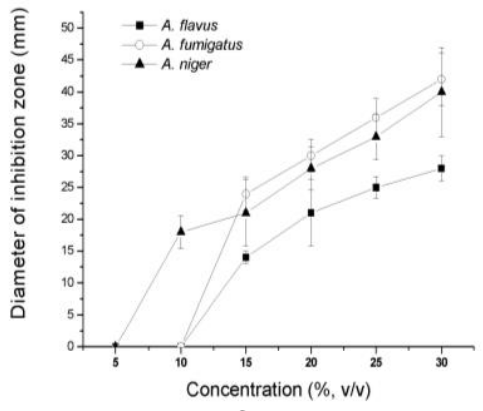

a

$\mathrm{P}<0.05$ at all the tested concentrations except at 20\% ( $\mathrm{p}=0.07)$. This indicates that the inhibitory effect of the essential oil at 15,25 and 30 was significant on the tested aspergilli. $\mathrm{P}<0.01$ at the concentration $25 \%$. This indicates that the inhibitory effect of this concentration on the tested aspergilli was high significant.

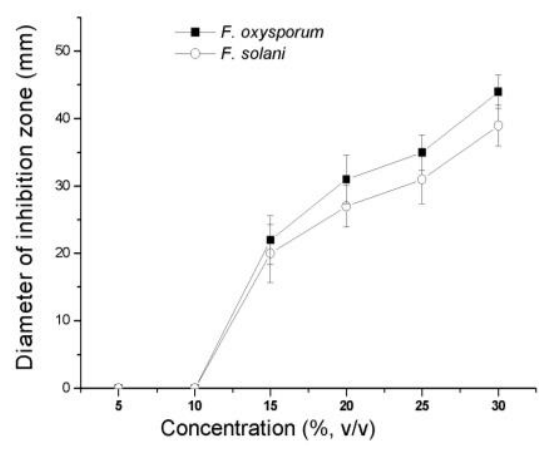

c

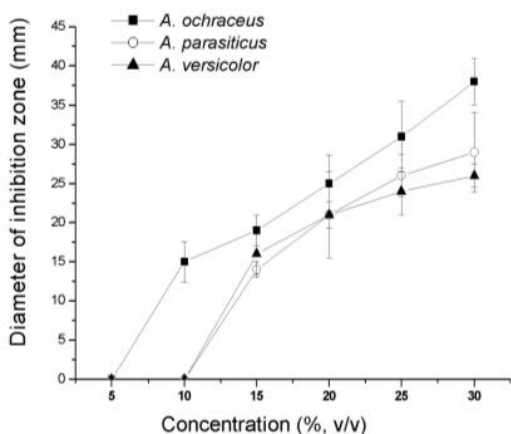

b

$\mathrm{P}>0.05$ at all the tested concentrations except at $30 \%$ $(\mathrm{P}=0.019)$. This indicates that $30 \%$ was the lonely concentration that showed significant inhibitory effect on the tested aspergilli.

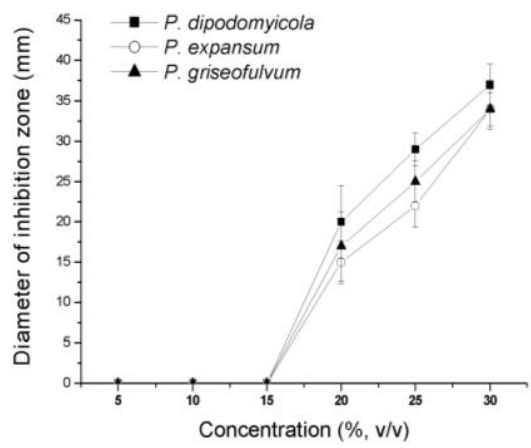

d

$\mathrm{P}<0.05$ at the concentration $25 \%$. This indicates that $25 \%$ is the lonely concentration that showed significant inhibitory effect on the tested Penicillium species.

Fig.1. Inhibitory effect (represented by inhibition zones diameters, mm) of various concentrations of Ocimum basilicum L. essential oil on the growth of the isolated toxigenic fungi. 


\section{Conclusion}

The present study is the first survey on moulds associated with Egyptian smoke-dried herring fish and capable of mycotoxin production by several species of Aspergillus, Penicillium and Fusarium. This constitutes not only an economic problem, but also a potential health hazard. The results also indicated that the diluted preparations of $O$. basilicum essential oil showed a broad spectrum of antifungal activity against the growth of toxigenic moulds contaminating smoke herring fish. So, O. basilicum essential oil appears to have promise as a safe alternative natural food preservative. Further work should focus on identifying the most important contamination sources of smoke-dried herring fish and possible preventive measures in the production and preservation process.

Acknowledgment: My sincere thanks to Prof. Dr. El-Sayed A. El-Sayed, Botany Department, Faculty of Science, Zagazig Univ. for valuable advice and constructive criticism during progress of this work. I am also grateful to Prof. Dr. Said M. Ezzat, Botany Department, Faculty of Science, Zagazig Univ., Egypt, for providing standard aflatoxins, citrinin and ochratoxin A (Sigma Co.), Ahmed Askora, Ph.D. student, Department of Molecular Biotechnology, Graduate School of Advanced Sciences of Matter, Hiroshima Univ., Japan, for providing standard cyclopiazonic acid (Wako Co.) and zearalenone (Sigma Co.) and Neven S. Metwaley, M.Sc. student, Botany Department, Faculty of Science, Zagazig Univ., Egypt, for providing standard kojic acid (Sigma Co.).

\section{References}

Aziz, N.H., Youssef, Y.A., El-Fouly, M.Z. and Moussa, L.A. (1998) Contamination of some common medicinal plant samples and spices by fungi and their mycotoxins. Bot. Bull. Acad. Sin., 39, 279- 285.

Aziz, N.H. and Moussa, L.A.A. (2002) Influence of gamma-radiation on mycotoxin producing moulds and mycotoxins in fruits. Food Control, 13, 281-288.

Bamba, R. and Sumbali, G. (2005) Co-occurrence of aflatoxin $B_{1}$ and cyclopiazonic acid in sour lime (Citrus aurantiofolia Swingle) during post-harvest pathogensis by Aspergillus flavus. Mycopathologia, 159, 407- 411.

Bentley, R. (1957) Preparation and analysis of kojic acid. Methods in Enzymology, 3 , 238- 241.

Bentley, R. and Keil, J. G. (1962) Tetronic acid biosynthesis in molds. II. Formation of penicillic acid in Penicillium cyclopium. J. Biol. Chem. 237(3), 867-873.

Borel, J. F. (1986) Cyclosporin and its future. Prog. Allergy, 38, 9- 18.

Burt, S. (2004) Essential oils: their antibacterial properties and potential applications in food- a review. Int. J. Food Microbiol. 94(3), 223- 253.

Egypt. J. Microbiol. 45 (2010) 
Cary, J.W. and Ehrlich, K.C. (2006) Aflatoxigenicity in Aspergillus: molecular genetics, phylogenetic relationships and evolutionary implications. Mycopathologia, 162 (3), 167- 177.

Ciegler, A. and Kurtzman, C.P. (1970) Fluorodensitometric assay of penicillic acid. $J$. Chromatogr. 51, 511- 516.

Ciegler, A., Vesonder, R.F. and Jackson, L.K. (1977) Production and biological activity of patulin and citrinin from Penicillium expansum. Appl. Environ. Microbiol., 33(4), 1004- 1006.

Cole, R.J., Kirksey, J.W. and Holaday, C. E. (1970) Detection of griseofulvin and dechlorogriseofulvin by thin-layer chromatography and gas liquid chromatography. Appl. Microbiol., 19 (1), 96- 102.

Domsch, K.H., Gams, W. and Anderson, T. H. (1980) "Compendium of Soil Fungi", Vol.1, Academic Press, A subsidiary of Horcourt, Brace, Jovanovich Publishers, London.

Domsch, K.H., Gams, W. and Anderson, T. H. (1981) "Compendium of Soil Fungi", Vol.1 and 2, Academic Press, London.

Doster, M.A., Michailides, T. J. and Morgan, D.P. (1996) Aspergillus species and mycotoxins in figs from Californian orchards. Plant Dis. 80, 484- 489.

Dreyfuss, M., Härri, E., Hofmann, H., Kobel, H., Pache, W. and Tscherter, H. (1976) Cyclosporin A and C, new metabolites from Trichoderma polysporum (Link ex pers.) Rifai. Eur. J. Appl. Microbiol., 3, 125- 133.

Ďuračková, Z., Betina, V. and Nemec, P. (1976) Systematic analysis of mycotoxins by thin-layer chromatography. J. Chromatogr., 116, 141-154.

El-Shanawany, A.A., Mostafa, M.E. and Barakat, A. (2005) Fungal populations and mycotoxins in silage in Assuit and Sohag governorates in Egypt, with a special reference to characteristic Aspergilli toxins. Mycopathologia, 59, 281- 289.

Essien, J.P., Ekpo, M.A. and Brooks, A.A. (2005) Mycotoxigenic and proteolytic potential of moulds associated with smoked shark fish (Chlamydoselachus angunicus). J. Appl. Sci. Environ. Mgt., 9(3), 53- 57.

Ezzat, S.M., El-Sayed, A.E., Abou El-Hawa, M.I. and Ismaiel, A.A. (2007) Morphological and ultrastructural studies for the biological action of penicillic acid on some bacterial species. Res. J. Microbiol., 2(4), 303- 314.

Fafioye, O.O., Efuntoe, M.O. and Osho, A. (2002) Studies on the fungal infestation of five traditionally smoke-dried freshwater fish in Ago-Iwoye, Nigeria. Mycopathologia, 154, 177- 179.

Fafioye, O.O., Fagbohun, T.R. and Olúbanjo, O.O. (2008) Fungal infestation and nutrient quality of traditionally smoke-dried freshwater fish. Turkish J. Fish Aquat. Sci., 8, 7- 13. 
Filtenborg, O., Frisvad, J.C. and Thrane, U.C. (1996) Moulds in food spoilage. Int. J. Food Microbiol., 33, 85- 102.

Frisvad, J.C. and Samson, R.A. (2004) Polyphasic Taxonomy of Penicillium subgenus Penicillium. A guide to identification of food and air-borne terverticillate penicillia and their mycotoxins. Studies in Mycology, 49, 1- 174.

Galvano, F., Piva, A., Ritieni, A. and Galvano, G. (2001) Dietary strategies to counteract the effects of mycotoxins. A review J. Food Protect. 64(1), 120- 131.

Gilman, J.C. (1957) " A manual of Soil Fungi”. Iowa State Univ. Press, Ames. Iowa, USA.

Grost-Allman, C.P. and Steyn, P.S. (1979) Screening methods for the detection of thirteen common mycotoxins. J. Chromatogr. 175, 325- 331

Jiménez, M., Mateo, R., Querol, A., Huerta, T. and Hernández, E. (1991) Mycotoxins and mycotoxigenic moulds in nuts and sunflower seeds for human consumption. Mycopathologia, 115, 121- 127.

Jonsyn, F.E. and Lahai, G.P. (1992) Mycotoxic flora and mycotoxins in smoke-dried fish from Sierra Leone. Die Nahrung, 36(5), 485- 489.

Koba, K., Poutouli, P.W., Raynaud C. and Sanda, K. (2009) Antifungal activity of the essential oil from Ocimum gratissimum L. grown in Togo. J. Sci. Res. 1 (1), $164-171$.

Lin, M.T. and Dianese, J.C. (1976) A coconut-agar medium for rapid detection of aflatoxin production by Aspergillus spp. Phytopathology, 66, 1466- 1469.

López-Diáz, T.M., Román-Blanco, C., García-Arias, M.T., García-Fernández, M.C. and García-López, M.L. (1996) Mycotoxins in two Spanish cheese verities. Int. J. Food Microbiol. 30, 391- 395.

Macri, A., Dancea, Z. and Baba, A. I. (2002) Mycotoxin involvement in oncogenesis: bibliographical investigations. Buletinul Universitii de Stiinte Agricole si Medicina Veterinara Cluj Nopoca. Seria Medicina Veterinara, 58, 640- 644.

Magan, N., Sanchis, V. and Akdred, D. (2004) Role of spoilage fungi in seed deterioration. In: "Fungal Biotechnology in Agricultural, Food and Environmental Applications", Aurora, D.K. (Ed), pp. 311-323. Chapter 28, Marcell Dekker.

Meronuck, R.A., Garren, K.H., Christensen, C.M., Nelson, G. H. and Bates, F. (1970) Effects on turkey poults and chicks of rations containing corn invaded by Penicillium and Fusarium species. Am. J. Vet. Res. 31, 551- 555.

Mihatsch, M.L., Steiner, K., Abeywickrama, K.H., Landmann, J. and Thiel, G. (1995) Risk factors for the development of chronic cyclosporine-nephrotoxicity. Clin Nephrol. 29, 165- 175 .

Mphande, F.A., Siame, B.A. and Taylor, J.E. (2004) Fungi, aflatoxins and cyclopiazonic acid associated with peanut retailing in Botswana. J. Food Protect. 67(1), 96- 102.

Egypt. J. Microbiol. 45 (2010) 
Nguefack, J., Lekagne Dongmo, J.B., Dakole, C.D., Leth, V., Vismer, H. F., Torp, J., Guemdjom, E.F.N., Mbeffo, M., Tamgue, O., Fatio, D., Amvam Zollo, P.H. and Nkengfack, A.E. (2009) Food preservative potential of essential oils and fractions from Cymbopogon citratus, Ocimum gratissimum and Thymus vulgaris against mycotoxigenic fungi. Int. J. Food Microbiol., 131(2-3), 151- 156.

Norman, N. and Joseph, H.H. (1996) "Food Science" $5^{\text {th }}$ ed. CBS Publication, Daryaganj, New Delhi.

Oplachenova, G. and Obreshkova, D. (2003) Comparative studies on the activity of basil- an essential oil from Ocimum basilicum L. - against multidrug resistant clinical isolates of the genera Staphylococcus, Enterococcus and Pseudomonas by using different test methods. Microbiological Methods, 54 (1) , 105- 110.

Oyewole, B.A., Agun, B.J. and Omotayo, K.F. (2006) Effects of different sources of heat on the quality of smoked fish. J. Food Agri. Environ., 4(2), 95- 97.

Piyo, A., Uomsilp, J., Khang-Khun, P. and Thobunluepop, P. (2009) Antifungal activity of essential oils from basil (Ocimum basilicum Linn.) and sweet fennel (Ocimum gratissimum Linn.): Alternative strategies to control pathogenic fungi in organic rice. As. J. Food Ag-Ind, Special Issue, S2-S9.

Raper, K.B. and Fennel, D.I. (1965) "The genus Aspergillus". Baltimore MD: Williams and Wilkins Co., Baltimore, Maryland, USA.

Richardson, K.E., Hagler, W.M., Campbell, C.L. and Hamilton, P.B. (1985) Production of zearalenone, T-2 toxin and deoxynivalenol by Fusarium spp. isolated from plant materials grown in North Carolina. Mycopathologia, 90, 155- 160.

Saggiorato, A.G., Gaio, I., Treichel, H., de Oliveira, D., Cichoski, A.J. and Cansian, R.L. (2009) Antifungal activity of basil essential oil (Ocimum basilicum L.): Evaluation in vitro and on an Italian-type sausage surface. Food Bioprocess Technol., DOI 10.10071S11947-009-0310-z.

Sallam, L.A., El-Refai, A.H., Hamdy, A.A., El-Minofi, H.A. and Abdel-Salam, I.S. (2003) Role of some fermentation parameters on cyclosporin A production by a new isolate of Aspergillus terreus. J. Gen. Appl. Microbiol. 49, 321- 328

Samson, R.A., Noonim, P., Meijer, M., Houbraken, J., Frisvad, J.C. and Vagra, J. (2007 a) Diagnostic tools to identify black aspergilli. Studies in Mycology, 59, $129-145$.

Samson, R.A., Hong, S., Peterson, S.W., Frisvad, J.C. and Vagra, J. (2007b) Polyphasic taxonomy of Aspergillus section Fumigati and its telemorph Neosartorya. Studies in Mycology, 59, 147- 203.

Sanchis, V., Scott, P.M. and Farber, J.M. (1988) Mycotoxin-producing potential of fungi isolated from red kidney beans. Mycopathologia, 104, 157- 162.

Sawai, K., Okuno, T., Terada, Y., Harada, Y., Sawamura, K., Sasaki, H. and Takao, S. (1981) Isolation and properties of two fungal substances from Fusarium solani. J. Biol. Chem. 45(5), 1223- 1228. 
Scott, P.M., Lawrence, J.W. and van Walbeek, W. (1970) Detection of mycotoxins by thin-layer chromatography: Application to screening of fungal extracts. Appl. Microbiol. 20(5), 839- 842.

Singh, K., Frisvad, J. C., Thrane, U. and Mathur, S.B. (1991) “An Illustrated Manual on Identification of Some Seed-Borne Aspergilli, Fusaria, Penicillia and their Mycotoxins", Jordburgsforlaget, Frederiksberg, Denmark, 133 pp.

Soylu, S., Yigitbas, H., Soylu, E.M. and Kurt, S. (2007) Antifungal effects of essential oils from Oregano and Fennel on Sclerotinia sclerotiorum. J. Appl. Microbiol. 103 (4), 1021- 1030 .

Suppakul, P., Miltz, J., Sonneveld, K. and Bigger, S.W. (2003) Antimicrobial properties of basil and its possible application in food packaging. J. Agric. Food Chem. 51 (11), 3197- 3207.

Thompson, D.P. (1989) Fungitoxic activity of essential oil components on food storage fungi. Mycologia, 81, 151- 153.

Van der Watt, J.J. (1974) Sterigmatocystin,. In: "Mycotoxins". I. F. H Purchase (Ed.), p.369-382, Elsevier Scientific Publishing Co., New York.

Viyoch, J., Pisutthanan, N., Faikreuaa, A., Nupangta, K., Wangtorpol, K. and Ngokkuen, J. (2006) Evaluation of in vitro antimicrobial activity of Thai basil oils and their micro-emulsion formulas against Propionibacterium acnes. Int. J. Cosmetics Sci. 28, $125-133$.

Wyllie, T.D. and Morehouse, L.G. (1977) Mycotoxic fungi, mycotoxins, mycotoxicoses. An Encyclopedic Hand Book, Vol. I. "Mycotoxic Fungi and Chemistry of Mycotoxins". Marcel Dekker, Inc, New York and Basel.

Yu, J., Mohawed, S.M., Bhatnagar, D. and Cleveland, T.E. (2003) Substrate-induced lipase gene expression and aflatoxin production in Aspergillus parasiticus and Aspergillus flavus. Appl. Microbiol. 95, 1334- 1342. 


\title{
تواجد الفطريات السامة في أسماك الرنجة المصرية الجافةت.

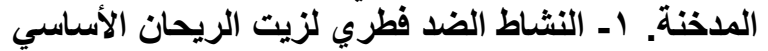

\author{
أحمد عبد الرحمن إسماعيل \\ قسم النبات - كلية العلوم - جامعة الزقازيق - الزقازيق - مصر.
}

\begin{abstract}
في هذا البحث ، تم عمل مسح لعزل الفطريات وتقييم تو اجدها في عينات مختلفة

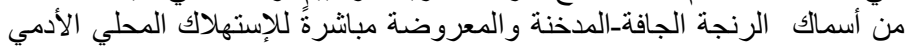

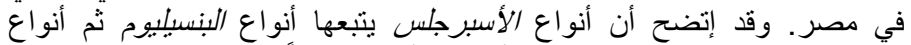

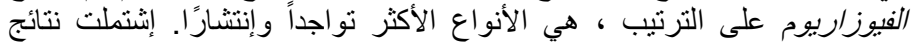

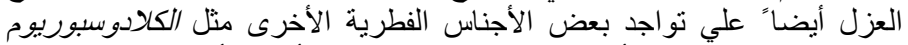

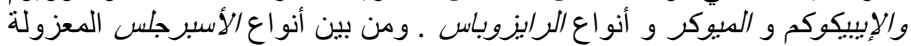

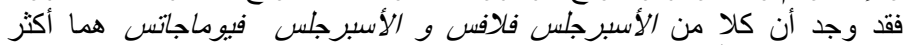

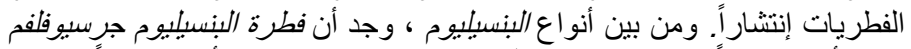

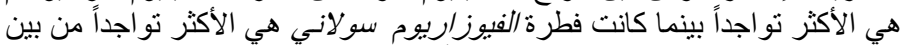

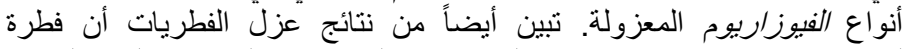

الكلادوسبوريوم كالادوسبوريوديبس لها تواجد عالي من بين الفطريات المعزولة.

أوضحت نتائج تحاليل السموم الفطرية الهنتجة بواسطة الفطريات الدعزولة أن

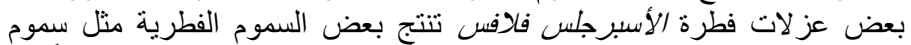

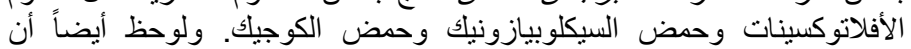

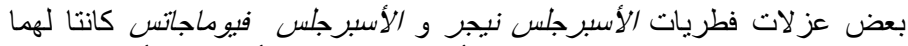

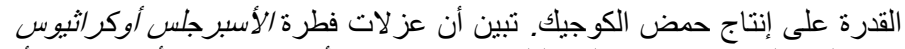

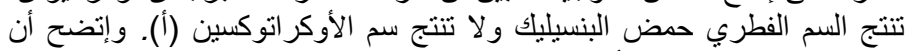

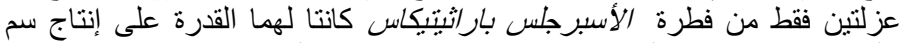

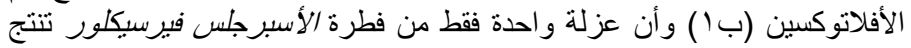

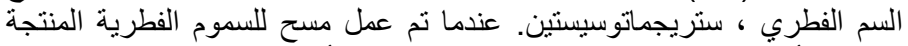

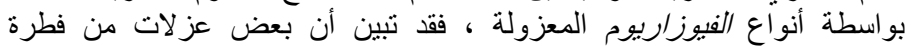

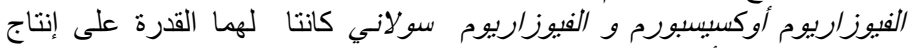
السيكلوسبورين (أ) و الزير الينون.

أظهرت نتائج تحاليل إنتاج السموم الفطرية لأنواع من البنسليوم أن المضاد الفيواد

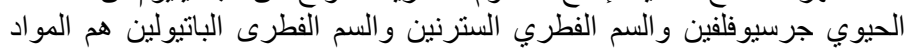
الميزة والمنتجة بواسطة انواع البنسيليوم السامة المعزولة.

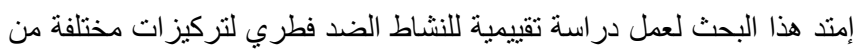

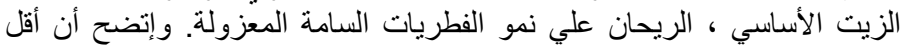

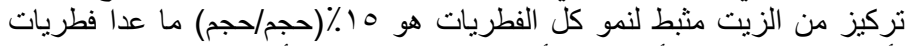

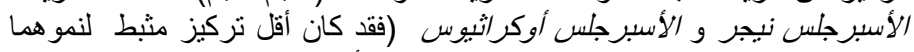

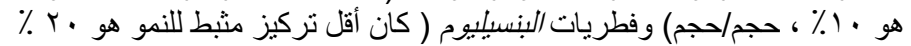

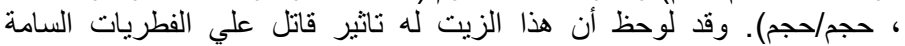

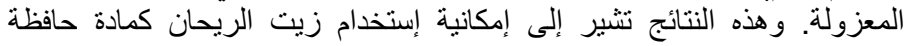
طبيعية كبديل للإضافات الكيمائية.
\end{abstract}

